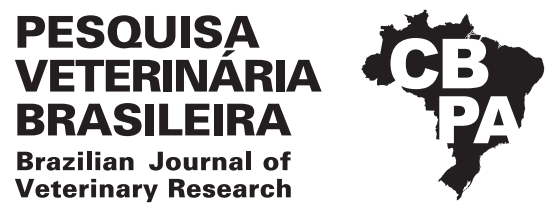

Pesq. Vet. Bras. 38(11):2124-2128, novembro 2018 DOI: 10.1590/1678-5150-PVB-5132

Original Article

Pequenos Animais/Small Animals Diseases

ISSN 0100-736X (Print)

ISSN 1678-5150 (Online)

\title{
Acute phase proteins in bitches subjected to conventional and minimally invasive ovariohysterectomy ${ }^{1}$
}

\author{
Elizabeth M.S. Schmidt ${ }^{2 *}$, Camila P. Rubio ${ }^{3}$, Funmilola Thomas ${ }^{4}$, João C.P. Ferreira ${ }^{2}$ \\ and David P. Eckersall ${ }^{5}$
}

\begin{abstract}
Schmidt E.M.S., Rubio C.P., Thomas F., Ferreira J.C.P. \& Eckersall D.P. 2018. Acute phase proteins in bitches subjected to conventional and minimally invasive ovariohysterectomy. Pesquisa Veterinária Brasileira 38(11):2124-2128. Departamento de Clínica Veterinária, Faculdade de Medicina Veterinária e Zootecnia, Universidade Estadual Paulista, Campus de Botucatu, Rua Prof. Dr. Walter Maurício Correa s/n, Cx. Postal 560, Botucatu, SP 18618-681, Brazil. E-mail: elizabeth.schmidt@unesp.br

The aim of this study was to evaluate and to compare the possible inflammatory changes by screening acute phase proteins concentrations in healthy bitches subjected to ovariohysterectomy. Minimally invasive and conventional (laparotomy) ovariohysterectomies were performed in 17 client-owned adult female mixed breed dogs. Nine animals were subjected to minimally invasive and eight animals to conventional ovariohysterectomy. Blood samples were taken before surgery, 24, 48 hours, and seven days postoperatively. Serum C-reactive concentration was determined by a commercial ELISA kit and serum haptoglobin concentration was measured via hemoglobin binding assay, both previously validated for use in dogs. As the data did not meet the normal distribution criteria, the nonparametric Kruskall-Wallis was performed to compare quantitative variables between groups. One-way ANOVA and the Friedman test were used for multiple comparisons between time points, with a $\mathrm{P}<0.05$ considered significant. C-reactive protein concentration was significantly different $(\mathrm{P}<0.0001)$ at 24 hours postoperatively between groups. There was no significant difference in haptoglobin concentration between groups. C-reactive protein and haptoglobin concentrations were significantly different at 24 and 48 hours postoperatively for minimally invasive and conventional ovariohisterectomies. These findings provided an overview of the short-term inflammatory effects produced by minimally invasive and conventional ovariohysterectomies.
\end{abstract}

INDEX TERMS: Bitches, ovariohysterectomy, dogs, C-reactive protein, haptoglobin, surgery.

RESUMO.- [Proteínas de fase aguda em cadelas submetidas à ovariohisterectomia convencional e minimamente invasiva.] 0 objetivo deste trabalho foi avaliar e comparar o

\footnotetext{
${ }^{1}$ Received on February 13, 2018.

Accepted for publication on May 7, 2018.

${ }^{2}$ Departamento de Clínica Veterinária, Faculdade de Medicina Veterinária e Zootecnia, Universidade Estadual Paulista, Campus de Botucatu, Rua Prof. Dr. Walter Maurício Correa s/n, Cx. Postal 560, Botucatu, SP 18618-681, Brazil. *Corresponding author: elizabeth.schmidt@unesp.br

${ }^{3}$ Aluna Doutorado, Faculdad de Veterinaria, Universidad de Murcia, Avda. Teniente Flomesta 5, Murcia, 30003, Spain.

${ }^{4}$ Department of Veterinary Physiology and Pharmachology, College of Veterinary Medicine, Federal University of Agriculture Abeokuta, Abeokuta, Nigeria.

${ }^{5}$ Institute of Biodiversity, Animal Health and Comparative Medicine, College of Medical, Veterinary and Life Sciences, University of Glasgow, University Avenue, Glasgow G12 8QQ, United Kingdom.
}

efeito inflamatório, por meio da determinação de proteínas de fase aguda, produzido por dois protocolos cirúrgicos distintos de ovariohisterectomia em cadelas. Para tanto, foram determinadas as concentrações de proteína $\mathrm{C}$ reativa (CRP) e haptoglobina (Hp) de 17 cadelas, sem raça definida, adultas,, sendo nove animais submetidos à ovariohisterectomia pela técnica convencional por laparotomia e oito a ovariohisterectomia pela técnica minimamente invasiva. Para avaliar a resposta de fase aguda causada pelo trauma cirúrgico, amostras de sangue foram obtidas antes dos procedimentos cirúrgicos e em quatro momentos distintos após as cirurgias $(24,48$ horas e sete dias) para as dosagens de CRP e Hp, com kit comercial ELISA e via ensaio de ligação com a hemoglobina, respectivamente, validados para o uso em cães. Como não houve distribuição normal dos dados, utilizou-se o teste de Kruskall-Wallis 
para comparação das variáveis quantitativas entre os dois grupos. Os testes de Friedman e One-way ANOVA foram usados para comparações múltiplas entre os momentos avaliados, sendo considerado $\mathrm{P}<0,05$ como significante. Houve diferença significativa $(\mathrm{P}<0,0001)$ para as concentrações de CRP 24 horas após o procedimento cirúrgico entre os dois protocolos utilizados. Não houve diferença significativa para as concentrações de Hp entre os dois protocolos cirúrgicos. Foram evidenciadas alterações significativas para as concentrações de CRP e Hp 24 e 48 horas após as ovariohisterectomias, independentemente da técnica cirúrgica utilizada. As concentrações de CRP e Hp demonstraram o efeito inflamatório imediato induzido pela ovariohisterectomia convencional e minimamente invasiva.

TERMOS DE INDEXAÇÃO: Cadelas, ovariohisterectomia, proteína C reativa, haptoglobina, cirurgia.

\section{INTRODUCTION}

The acute phase response is part of the body's innate defense system (Eckersall \& Bell 2010), characterized by a systemic reaction caused by local or systemic disorders, promoted by infectious agents, trauma, and tissue injury, surgeries, neoplastic growth or immunological disorders (Ceron et al. 2005, Gruys et al. 2005, Eckersall 2008). During the acute phase response, there is increased synthesis and release of acute phase proteins (APP), induced by pro-inflammatory cytokines produced mainly by the liver and extrahepatic tissues such as adipose tissue, mammary gland and lungs. PFAs are classified according to changes in their concentrations in positive (C-reactive protein, haptoglobin, serum amyloid A) if they increase, or negative (albumin), if they decrease their concentrations during the acute phase response (Murata et al. 2004, Ceron et al. 2005).

Ovariohysterectomy is one of the most performed surgical procedures in companion animals and promotes the appearance of pain signals during the postoperative period in dogs (Lascelles et al. 1998). To minimize surgical trauma, minimally invasive techniques, such as endoscopic or laparoscopic surgeries, have been used as they cause less inflammatory reaction when compared to conventional surgical techniques (Suter et al. 2002, Kjelgaard-Hansen et al. 2013). In addition, the response to surgical stress is composed of a set of hormonal, metabolic and inflammatory reactions that occur after surgery, allowing the body to adapt to trauma and to recover damaged tissues (Jacobsen et al. 2009). In order to improve the surgical procedure and monitoring of the postoperative period, it is necessary to identify markers that are useful to evaluate the intensity of the trauma caused by the procedure. Recent investigations have demonstrated changes in APP concentrations in dogs related to the extent and progression of diseases, as well as their the inflammatory response in infectious, parasitic, trauma, degenerative diseases and neoplastic diseases (Bayramli \& Ulutas 2008, Koster et al. 2009, Tecles et al. 2009, Méndez et al. 2014, Schmidt \& Eckersall 2015, Hillström et al. 2016, Schmidt et al. 2016). However, although the acute phase response was investigated in dogs undergoing elective soft tissue surgeries (Serin \& Ulutas 2010, Kjelgaard-Hansen et al. 2013, Kum et al. 2013), surgical correction of obstructive airway syndrome (Planellas et al. 2015), nephrectomy (Schmidt et al. 2016), and ovariohysterectomy as the treatment of pyometra (Dabrowski et al. 2007, 2009) few studies have evaluated the PFA concentrations and the acute phase response dynamics in dogs undergoing minimally invasive surgical procedures (Mathon et al. 2011, Tvarijonaviciute et al. 2011, Kjelgaard-Hansen et al. 2013).

Therefore, the objective of this work is to evaluate and to explore possible differences between two conventional and minimally invasive ovariohysterectomy protocols in bitches regarding the kinetics of the acute protein response of CRP (C-reactive protein) and Hp (haptoglobin), comparing the effects of inflammation caused by the two procedures in the postoperative period.

\section{MATERIALS AND METHODS}

The study population comprised of 17 client-owned adult female mixed breed dogs ( 2 to 7 years old; $10 \pm 1,2 \mathrm{~kg}$ ), admitted to the São Paulo State University Veterinary Teaching Hospital of the Faculty of Veterinary Medicine and Animal Science (FVMZ) for elective ovariohysterectomy. Inclusion criteria included the availability of complete clinical records as part of the routine care and ultrasound evaluation discarding pregnancy. The stage of oestrus cycle was not determined. The dogs included in the study showed no abnormal findings on physical and clinical examination or any other considerable change in hemograms, alanine aminotransferase activity, total serum protein, albumin, and fibrinogen. This approach was approved by the Faculty's Animal Experimentation Ethics Committee of the São Paulo State University, FMVZ-Unesp, Campus Botucatu (protocol number 194/2011-CEUA) with the consent form signed by the owners under the same protocol.

The animals were fasted (food and water) for 12 hours before the surgical procedure. All bitches received meloxican $(0.2 \mathrm{mg} / \mathrm{kg}$, Maxicam $0.2 \%$, Ourofino, Brazil) pre-surgery, 15 minutes before induction of anesthesia. At the same time, the preanesthetic medication used was the combination of acepromazine maleate $(0.05 \mathrm{mg} / \mathrm{kg}$; Acepran $0.2 \%$, Vetnil, Brazil) and morphine $(0.5 \mathrm{mg} /$ kg; Dimorf, Cristalia, Brazil) via intramuscular. For anesthesia induction, the combination of ketamine $(10 \mathrm{mg} / \mathrm{kg}$; Quetamina, Vetnil, Brazil) and diazepam $(0.5 \mathrm{mg} / \mathrm{kg}$, Valium, Roche, Brazil) were used intravenously. The anesthetic protocol employed was adequate for performing the surgical procedure and lasted from 20 to 30 minutes, with no need for anesthetic complementation. After the surgical procedure, the animals received intravenous penicillin benzathine (24,000 IU, Veterinary Pentabiotic, Fort Dodge, Brazil) as a routine prophylactic measure.

The dogs were divided into two experimental groups. Group 1 (G1): 9 animals, submitted to ovariohysterectomy by the conventional technique. Group 2 (G2): 8 animals, submitted to ovariohysterectomy by the minimally invasive technique. The conventional technique was performed by laparotomy. After the procedures of trichotomy and asepsis of the abdominal region, a ventral midline incision was performed over the skin, subcutaneous tissue and the linea alba. Then the uterus was exposed and the ligatures of the ovarian pedicles and uterine body were performed with mononylon 2-0 yarn. Once the uterus and ovaries were removed, abdominal wall synthesis was performed with Sultan-type suture, and subcutaneous tissue using a simple continuous pattern of absorbable sutures and the skin was closed in a simple interrupted pattern. The stitches were removed seven days after the surgical procedure (Stone 2007).

For the minimally invasive technique, the animals were placed in dorsal decubitus position. After the trichotomy and asepsis of 
the region of the abdomen, a midline skin incision of about two centimeters was performed caudal to the umbilical scar. Then the linea alba was incised and the abdominal cavity was accessed. The uterine horns and the ovarian pedicles were pulled into a midline portal with the aid of a spay hook and the ovarian ligament dissected, thus pulling the ovaries and ovarian pedicles which were ligated with a self-static nylon cable tie. Subsequently, the uterine horns were pulled into the midline incision and the cervix was ligated using the same nylon cable tie. Abdominal wall synthesis was performed with Sultan-type suture, and subcutaneous tissue using a simple continuous pattern of absorbable sutures and the skin was closed in a simple interrupted pattern as described by Silva et al. (2004) and Lima et al. (2010). All surgical procedures of G1 and G2 were performed by a single surgeon, but a different person for each group.

Blood samples were obtained by jugular vein puncture $24 \mathrm{~h}$ preoperatively (M1) and at three time points postsurgery, i.e. $24 \mathrm{~h}$ (M2), 48h (M3), and on day 7 after surgery (M4). Aliquots of the samples $(3 \mathrm{~mL})$ were placed in plain tubes with gel separators (BD Vacutainer ${ }^{\circledR}$ Blood Collection Tube; Becton, Dickinson and Company, USA) were allowed to clot at room temperature, centrifuged $(1,500 \times \mathrm{g}$ for $5 \mathrm{~min})$ and the harvest sera were stored in Eppendorf microtubes (Eppendorf, Hamburg, Germany), stored at $-20^{\circ} \mathrm{C}$ with CRP and haptoglobin analyses performed within six months.

Serum CRP concentrations were determined by a commercial ELISA kit (cCRP; Avacta, York, UK) based on a previous assay validated for use in dogs (Eckersall et al. 1989). Serum HP concentrations were measured via a hemoglobin binding assay previously validated for use in dogs (Crawford et al. 2013). These assays showed a within run imprecision of less than $10 \%$.

All statistics were performed using statistical software (GraphPad Version 6 for Windows, GraphPad Software Inc., San Diego/CA, USA). All variables were first assessed for normality using the Shapiro-Wilk test. The nonparametric Kruskal-Wallis test was used to compare the groups and One-way ANOVA and Friedman test was used for multiple comparisons between groups as the data was not normally distributed. Mann-Whitney U test was used for additional comparisons between groups. Statistical significance was set at $\mathrm{P}<0.05$ for all analyses.

\section{RESULTS}

The preanesthetic and anesthetic protocols were adequate to perform the surgical procedures in both groups. Surgical procedures ranged from 20-30 minutes in G1 and 15-20 minutes in G2. There were no intercurrences or complication in all performed surgeries, regardless of the technique employed, until the stitches were removed.

Haptoglobin and CRP concentrations from all dogs of G1 and G2 are presented in Table 1. C-reactive protein concentration was significantly higher $(\mathrm{P}<0.0001)$ at $24 \mathrm{~h}$ after the surgical procedures for both ovariohysterectomy techniques. There were no significant differences for Hp between both surgical protocols. The median concentrations of CRP were significantly higher when comparing 24 and 48h after surgery to before minimally invasive and conventional ovariohysterectomy. In our study, the median haptoglobin concentrations were significantly higher $48 \mathrm{~h}$ after conventional ovariohysterectomy and at 24 and $48 \mathrm{~h}$ after the minimally invasive surgery.

Significant differences for G1 and G2 were not observed for CRP and Hp on day 7 after surgeries (Table 1).
Table 1. Median and range (minimum - maximum) of CRP $(\mu \mathrm{g} / \mathrm{mL})$ and $\mathrm{Hp}(\mathrm{g} / \mathrm{L})$ concentrations in female dogs subjected to conventional $(n=9)$ and minimally invasive ovariohysterectomy $(n=8)$ at four different time points

\begin{tabular}{lccccc}
\hline & \multicolumn{2}{c}{$\mathrm{CRP}(\mu \mathrm{g} / \mathrm{mL})$} & & \multicolumn{2}{c}{$\mathrm{Hp}(\mathrm{g} / \mathrm{L})$} \\
\cline { 2 - 3 } \cline { 5 - 6 } & $\mathrm{G} 1$ & $\mathrm{G} 2$ & & $\mathrm{G} 1$ & $\mathrm{G} 2$ \\
\hline Before & $5 \mathrm{Aa}$ & $5.4 \mathrm{Aa}$ & & $1.3 \mathrm{a}$ & $1.0 \mathrm{a}$ \\
surgery & $(5-5.8)$ & $(5-10)$ & & $(0.1-2.4)$ & $(0.7-2.8)$ \\
24h after & $71.7 \mathrm{Ab}$ & $31.1 \mathrm{Bb}$ & & $1.8 \mathrm{ab}$ & $4.7 \mathrm{~b}$ \\
surgery & $(26.1-94.7)$ & $(12-57.3)$ & & $(0.5-6.8)$ & $(2.2-6.6)$ \\
48h after & $26.1 \mathrm{Aab}$ & $16.8 \mathrm{Aab}$ & & $3.3 \mathrm{~b}$ & $4.7 \mathrm{~b}$ \\
surgery & $(18.6-56.2)$ & $(5-31.1)$ & & $(0.5-9.4)$ & $(1.9-7.9)$ \\
7 days & $10.5 \mathrm{Aa}$ & $9.9 \mathrm{Aa}$ & & $2.0 \mathrm{ab}$ & $1.7 \mathrm{a}$ \\
after & $(5-22.7)$ & $(5-24)$ & & $(0.2-6.9)$ & $(0-3)$ \\
surgery & & & & & \\
$P$ value & $<0.0001$ & $<0.0001$ & & $<0.0072$ & $<0.0002$
\end{tabular}

G1 = Conventional ovariohysterectomy, G2 = minimally invasive ovariohysterectomy. Different capital letters in the same line indicate significant difference between surgical protocols, lowercase letters in the same column indicate significant difference between time points.

\section{DISCUSSION}

CRP is the major acute phase protein in dogs and also a consistent marker of inflammation in this species, stimulated by the inflammatory response increasing up to 10 - to 100 -fold (Ceron et al. 2005, Eckersall 2008). Haptoglobin is considered a moderate acute phase protein in dogs and has also been used as a nonspecific biomarker of inflammation, but there is an APP pattern that has been described in dogs with hyperadrenocorticism (McGrotty et al. 2003, Caldin et al. 2009) and in dogs infected by the giant kidney worm (Dioctophyme renale) (Schmidt et al. 2016), with increased Hp concentration indicating a stress response due to increased endogenous cortisol concentration (Caldin et al. 2009).

The acute phase response observed in the dogs of this study consisted of increased CRP and Hp serum concentrations after ovariohysterectomy. These increases are related to the inflammatory response induced by pro-inflammatory cytokines interleukin-1, interleukin-6 and alpha tumor necrosis factor, which stimulate synthesis and release of APP by the liver (Gruys et al. 2005, Eckersall 2008). In our study, these results could evidence an acute inflammatory response as the median concentrations of CRP and Hp were above the reference intervals for dogs (CRP $<12 \mu \mathrm{g} / \mathrm{mL}, \mathrm{Hp}<3$ g/L) (Eckersall et al. 1999, Ceron et al. 2005), from 24 hours after the surgical procedure, similarly to those described previously for acute phase proteins after surgical trauma in dogs (Conner et al. 1988, Dabrowski et al. 2007, 2009, Tvarijonaviciute et al. 2011, Kjelgaard-Hansen et al. 2013, Schmidt et al. 2016).

The increased CRP concentrations at M2 found in dogs after conventional and minimally invasive ovariohysterectomy could reflect the systemic reaction of the surgical trauma. Bitches subjected to ovariohysterectomy by laparotomy demonstrated a cumulative increased CRP concentration postsurgery, peaking at $12 \mathrm{~h}$ after the surgical procedure indicating that this could be the appropriate time point to evaluate the inflammatory impact of surgical trauma (Kjelgaard-Hansen et al. 2013). This response was also expected in our study; however, despite 
increased CRP at $24 \mathrm{~h}$ postsurgery, this result indicates a limitation of our investigation as it was not possible to obtain serum samples at the immediate postsurgical time points, i.e. at 4, 8, and $12 \mathrm{~h}$, as described by Kjelgaard-Hansen et al. (2013).

Conner et al. (1988), Dabrowski etal. (2009), and Kum etal. (2013) demonstrated that CRP concentration reaches a peak at $24 \mathrm{~h}$ after the surgical trauma and there is a rapid decrease of CRP in the absence of postoperative complications. However, there was a different inflammatory response in bitches subjected to ovariohysterectomy by laparotomy with increased CRP concentrations from 24h until day 7 after surgery, demonstrating that although there could have been a decrease in inflammation, CRP remained increased (Serin \& Ulutas 2010). No changes were observed in CRP concentration on day 7 postsurgery of the female dogs evaluated in this study. Despite the ovariohysterectomy technique, this indicates that the recovery from the inflammation associated with the surgery was complete.

In our study, no changes were observed for $\mathrm{Hp}$ concentrations between both surgical protocols. However, a hypothesis explaining why dogs subjected to conventional ovariohysterectomy present decreased serum Hp concentration at 24 and $48 \mathrm{~h}$ post-surgery compared to dogs subjected to minimally invasive ovariohisterectomy would be that the highest degree of hemolysis immediately after surgery $(24 \mathrm{~h})$ occurs due to a larger tissue injury and the decrease in $\mathrm{Hp}$ concentration could be caused by the monocyte/macrophage Hp-hemoglobin receptor expressed on Kupffer cells in the liver and the further removal of this complex (Conner et al. 1988, Eckersall 2008).

Haptoglobin is a moderate APP and usually peaks at 24 to 48h after a surgical trauma (McGrotty et al. 2003, Eckersall 2008). Haptoglobin concentrations were above reference intervals for the bitches $(\mathrm{Hp}<3 \mathrm{~g} / \mathrm{L}$ ) (Eckersall et al. 1999) at $24 \mathrm{~h}$ after the minimally invasive ovariohysterectomy as well as at $48 \mathrm{~h}$ for both surgical procedures. These results could indicate a mild inflammatory response that could be associated with an inflammatory response of lower intensity after the initial surgical trauma. Dabrowski et al. (2009) and Serin \& Ulutas (2010) demonstrated the same inflammatory response in bitches subjected to ovariohysterectomy by laparotomy.

Repeated measurements of CRP and Hp were useful in monitoring the short-term inflammatory process induced by the ovariohysterectomy that was associated with increases in serum concentration of both APPs. No further significant increases were recorded 7 days after conventional and minimally invasive ovariohysterectomy, when recovery from the inflammation associated with the surgery was complete.

\section{CONCLUSIONS}

Bitches were subjected to conventional and minimally invasive ovariohysterectomy that contributes towards an understanding of the postsurgical inflammatory response in dogs subjected to elective ovariohysterectomy.

Both surgical procedures increased CRP and Hp concentrations at different time points due to surgical trauma, demonstrating the usefulness of determining the concentrations of these proteins to monitoring the short-term inflammatory process induced by the ovariohysterectomy.
Conflict of interest.- None of the authors of this article has a financial or personal relationship with other people or organizations that could inappropriately influence the content of the paper.

Acknowledgments.- The authors mention that part of the present work was carried out at the Institute of Biodiversity, Animal Health and Comparative Medicine, College of Medical, Veterinary and Life Sciences, University of Glasgow, UK, supported by a Marie Curie Grant (FP07 Nematode Health System) - ITN 2012-264639 (Ems Schmidt Training Fellow Grant) and partially supported by CAPES - Brazil. Our gratitude extends to Mary Waterstone from the University of Glasgow for the help with the laboratory analyses, to Dr. Alfredo Feio da Maia Lima, Thalles Amaro Rodrigues, Rodrigo Guidio Dálio, Guilherme Cardoso, and Gisele Junqueira dos Santos.

\section{REFERENCES}

Bayramli G. \& Ulutas B. 2008. Acute phase protein response in dogs with experimentally induced gastric mucosal injury. Vet. Clin. Pathol. 37(3):312-316. <http://dx.doi.org/10.1111/j.1939-165X.2008.00060. $\mathrm{x}><$ PMid:18761525>

Caldin M., Tasca S., Carli E., Bianchini S., Furlanello T., Martinez-Subiela S. \& Cerón J.J. 2009. Serum acute phase protein concentrations in dogs with hyperadrenocorticism with and without concurrent inflammatory conditions. Vet. Clin. Pathol. 38(1):63-68. <http://dx.doi.org/10.1111/j.1939165X.2008.00087.x><PMid:19228354>

Ceron J.J., Eckersall P.D. \& Martýnez-Subiela S. 2005. Acute phase proteins in dogs and cats: current knowledge and future perspectives. Vet. Clin Pathol. 34(2):85-99. <http://dx.doi.org/10.1111/j.1939-165X.2005 tb00019.x><PMid:15902658>

Conner J.G., Eckersall P.D., Ferguson J. \& Douglas T.A. 1988. Acute phase response in the dog following surgical trauma. Res. Vet. Sci. 45(1):107-110. <http://dx.doi.org/10.1016/S0034-5288(18)30902-0><PMid:2464844>

Crawford K., Warman S.M., Marques A.I., Yool D.A., Eckersall P.D., McCulloch E., Lynn K., Mellanby R.J. \& Gow A.G. 2013. Serum haptoglobin concentrations in dogs with liver disease. Vet. Rec. 173(23):579-582. <http://dx.doi. org/10.1136/vr.101306><PMid:24158322>

Dabrowski R., Wawron W. \& Kostro K. 2007. Changes in CRP, SAA and haptoglobin produced in response to ovariohysterectomy in healthy bitches and those with pyometra. Theriogenology 67(2):321-327. <http://dx.doi. org/10.1016/j.theriogenology.2006.07.019><PMid:16962655>

Dabrowski R., Kostro K., Lisiecka U., Szczubiał M. \& Krakowski L. 2009 Usefulness of C-reactive protein, serum amyloid A component, and haptoglobin determinations in bitches with pyometra for monitoring early post-ovariohysterectomy complications. Theriogenology 72(4):471-476 <http://dx.doi.org/10.1016/j.theriogenology.2009.03.017><PMid:19477501>

Eckersall P.D. 2008. Proteins, proteomics and the dysproteinemias, p.117155. In: Kaneko J.J., Harvey J.W. \& Bruss M.L. (Eds), Clinical Biochemistry of Domestic Animals. 6th ed. Academic Press, Burlington. <http://dx.doi. org/10.1016/B978-0-12-370491-7.00005-2>.

Eckersall P.D. \& Bell R. 2010. Acute phase proteins: biomarkers of infection and inflammation. Vet. J. 185(1):23-27. <http://dx.doi.org/10.1016/j. tvjl.2010.04.009><PMid:20621712>

Eckersall P.D., Conner J.G. \& Parton H. 1989. An enzyme-linked immunosorbent assay for canine C-reactive protein. Vet. Rec. 124(18):490-491. <http:// dx.doi.org/10.1136/vr.124.18.490><PMid:2750033>

Eckersall P.D., Duthie S., Safi S., Moffatt D., Horadagoda N.U., Doyle S., Parton R., Bennett D. \& Fitzpatrick J.L. 1999. An automated biochemical assay for haptoglobin: prevention of interference from albumin. Comp. Haematol. Int. 9(3):117-124. <http://dx.doi.org/10.1007/BF02600369>

Gruys E., Toussaint M.J., Niewold T.A. \& Koopmans S.J. 2005. Acute phase reaction and acute phase proteins. J. Zhejiand Univ., Sci. B. Biomed. Biotechnol. 11:1045-1056. 
Hillström A., Bylin J., Hagman R., Björhall K., Tvedten H., Königsson K., Fall T. \& Kjelgaard-Hansen M. 2016. Measurement of serum C-reactive protein concentration for discriminating between suppurative arthritis and osteoarthritis in dogs. BMC Vet. Res. 12(1):240-249. <http://dx.doi. org/10.1186/s12917-016-0868-4><PMid:27793205>

Jacobsen S., Nielsen J.V., Kjelgaard-Hansen M., Toelboell T., Fjeldborg J., HallingThomsen M., Martinussen T. \& Thoefner M.B. 2009. Acute phase response to surgery of varying intensity in horses: a preliminary study. Vet. Surg. 38(6):762-769. <http://dx.doi.org/10.1111/j.1532-950X.2009.00564. $\mathrm{x}><$ PMid:19674420>

Kjelgaard-Hansen M., Strom H., Mikkelsen L.F., Eriksen T., Jensen A.L. \& Luntang-Jensen M. 2013. Canine serum C-reactive protein as a quantitative marker of the inflammatory stimulus of aseptic elective soft tissue surgery. Vet. Clin. Pathol. 42(3):342-345. <http://dx.doi.org/10.1111/vcp.12063> <PMid:23899087>

Koster L.S., Van Schoor M., Goddard A., Thompson P.N., Matjila P.T. \& KjelgaardHansen M. 2009. C-reactive protein in canine babesiosis caused by Babesia rossi and its associations with outcome. J. S. Afr. Vet. Assoc. 80(2):87-91. <http://dx.doi.org/10.4102/jsava.v80i2.177> <PMid:19831269>

Kum C., Voyvoda H., Sekkin S., Karademir U. \& Tarimcilar T. 2013. Effects of carprofen and meloxicam on C-reactive protein, ceruloplasmin, and fibrinogen concentrations in dogs undergoing ovariohysterectomy. Am. J. Vet. Res. 10(10):1267-1273. <http://dx.doi.org/10.2460/ajvr.74.10.1267> <PMid:24066910>

Lascelles B.D., Cripps P.J., Jones A. \& Waterman-Pearson A.E. 1998. Efficacy and kinetics of carprofen, administered preoperatively or postoperatively, for the prevention of pain in dogs undergoing ovariohysterectomy. Vet. Surg. 27(6):568-582. <http://dx.doi.org/10.1111/j.1532-950X.1998. tb00533.x><PMid:9845221>

Lima A.F.M., Luna S.P.L., Rodrigues M.M. \& Quitzan J. 2010. Avaliação histological e videolaparoscópica de ligaduras de pedículos ovarianos realizados com mononáilon agulhado ou abraçadeiras auto-estáticas de náilon em cadelas submetidas a ovariossalpingohisterectomia pela técnica do gancho. ARS Vet. 2:66-70.

Mathon D.H., Palierne S., Meynaud-Collard P., Layssol-Lamour C., DulaurentFerrieres A., Colson A., Lacroix M., Bousquet-Melou A., Delverdier M. \& Autefage A. 2011. Laparoscopic-assisted colopexy and sterilization in male dogs: short-term results and physiologic consequences. Vet. Surg. 40(4):500-508. <http://dx.doi.org/10.1111/j.1532-950X.2011.00835. $\mathrm{x}><$ PMid:21521243>

McGrotty Y.L., Knottenbelt C.M., Ramsey I.K., Reid S.W. \& Eckersall P.D. 2003. Haptoglobin concentrations in a canine hospital population. Vet. Rec. 152(18):562-564. <http://dx.doi.org/10.1136/vr.152.18.562> $<$ PMid:12751608>
Méndez J.C., Carretón E., Martínez S., Tvarijonaviciute A., Cerón J.J. \& Montoya-Alonso J.A. 2014. Acute phase response in dogs with Dirofilaria immitis. Vet. Parasitol. 204(3/4):420-425. <http://dx.doi.org/10.1016/j. vetpar.2014.05.016><PMid:24893697>

Murata H., Shimada N. \& Yoshioka M. 2004. Current research on acute phase proteins in veterinary diagnosis: an overview. Vet. J. 168(1):28-40. <http:// dx.doi.org/10.1016/S1090-0233(03)00119-9><PMid:15158206>

Planellas M., Cuenca R., Tabar M.D., Bertolani C., Poncet C., Closa J.M., Lorente J., Cerón J.J. \& Pastor J. 2015. Clinical assessment and C-reactive protein (CRP), haptoglobin (Hp), and cardiac troponin I (cTnI) values of brachycephalic dogs with upper airway obstruction before and after surgery. Can. J. Vet. Res. 79(1):58-63. <PMid:25673910>

Schmidt E.M.S. \& Eckersall P.D. 2015. Acute phase proteins as markers of infectious diseases in small animals. Acta Vet., Belgrade, 65:149-161.

Schmidt E.M.S., Kjelgaard-Hansen M., Thomas F., Tvarijonaviciute A., Cerón J.J. \& Eckersall P.D. 2016. Acute phase proteins in dogs naturally infected with the giant kidney worm (Dioctophyme renale). Vet. Clin. Pathol. 45(4):657664. <http://dx.doi.org/10.1111/vcp.12400><PMid:27748965>

Serin G. \& Ulutas P.A. 2010. Measurement of serum acute phase proteins to monitor postoperative recovery in anoestrous bitches after ovariohysterectomy. Vet. Rec. 166(1):20-22.<http://dx.doi.org/10.1136/ vr.b5585><PMid:20045854>

Silva L.A.F., Araújo G.R.S., Miranda A.H., Rabelo R.E., Garcia A.M., Silva O.C., Araújo I.F.L., Macedo S.P., Sousa J.N., Fioravanti M.C.S., Oliveira K.S., Amaral A.V.C. \& Silva E.B. 2004. Ovariohisterectomia em cadelas: uso da braçadeira de náilon na hemostasia preventiva. Ciênc. Anim. Bras. 5(Supl.):100-102.

Stone E.A. 2007. Ovário e útero, p.1487-1502. In: Slatter D. (Ed.), Manual de Cirurgia de Pequenos Animais. 3aㅡ ed. Manole, São Paulo.

Suter M., Martinet 0. \& Spertini F. 2002. Reduced acute phase response after laparoscopic total extraperitoneal bilateral hernia repair compared to open repair with the Stoppa procedure. Surg. Endosc. 16(8):1214-1219. <http://dx.doi.org/10.1007/s00464-001-9164-9><PMid:12189483>

Tecles F., Caldín M., Zanella A., Membiela F., Tvarijonaviciute A., Subiela S.M. \& Cerón J.J. 2009. Serum acute phase protein concentrations in female dogs with mammary tumors. J. Vet. Diagn. Invest. 21(2):214-219. <http://dx.doi. org/10.1177/104063870902100206> <PMid:19286500>

Tvarijonaviciute A., Martinez-Subiela S., Carrillo-Sanchez J.D., Tecles F. \& Ceron J.J. 2011. Effects of orchidectomy in selective biochemical analytes in Beagle dogs. Reprod. Domest. Anim. 6(6):957-963. <http://dx.doi. org/10.1111/j.1439-0531.2011.01765.x><PMid:21366720> 